Mira Beќar

UDK: $316.62: 316.7$

Ss Cyril and Methodius University

$316.77 ; 316.334 .56$

Blazhe Koneski Faculty of Philology

Прейледни научни рад

Skopje, R. Macedonia

Примљено: 26. 09. 2015.

m.bekar@flf.ukim.edu.mk

\title{
SPACE, LANGUAGE AND POWER: THE RHETORIC OF STREET PROTESTS
}

Summary: This paper explores the rhetoric of street protest banners and slogans used as a means of performing dissatisfaction and the role of the street where a network of relationships is built among actors with unequal power and with shared beliefs about specific social situations. Drawing upon Berns' (1995: 195) view that "for the $21^{\text {st }}$ century people, English serves a wider range of purposes, well beyond face-to-face contact through mass communication and media, including print, audio-visual, and electronic media, than ever before in history", and Bourdieu's (1989) discussion on the symbolic struggles over the perception of the social worlds, this paper focuses on the relationship between the use of English, as a means for communicating dissatisfaction at a global level, and the street, used as a medium for performing joint social action. The language and visual rhetoric of protest slogans and banners written in English were analyzed using the principles of visual rhetoric for the purposes of this study. The local contexts included Iran, Serbia, Macedonia, and Ukraine. This exploratory study shows how local historical and political imagery and the sense of belonging to the world-wide social and political processes are negotiated.

Keywords: street protest, social space, visual rhetoric, lingua franca, power.

\section{Introduction}

Discontent is a world-wide phenomenon. English is a world-wide phenomenon as well. We are aware, throughout history, that English is used as a language of discontent in many foreign countries that belong to the expanding circle. Although some scholars such as Phillipson (1997) claim that the use of English is a pure "linguistic imperialism and practice of power," this paper will try to demonstrate that English is also used for practicing the balance of power, which is only visible in protests.

Similarly to discontent, the street is a universal entity. It is a complex social space in which a network of relationships is built among actors with unequal power and with opposing beliefs about specific social situations, but at the same time, it is a space where social change occurs through socialization. The 1960s showed that power can be shifted from political leaders and governments to young generations, who knew how to ex- 
press their views in very creative ways. One of those ways is the so called resistance art or protest street art. Protest signs, posters, placards and demonstration slogans, as various types of resistance (protest) art, have a twofold function. They serve as protests against power, war, and dissatisfaction in general, but they also serve as signs of globalization, especially because they are written in English.

This paper will try to examine the function of English in foreign countries as a means of no-arms unrest and as a means of globalization. It will also examine the role of the street in the whole process of socialization during protest. This is an exploratory study of the function of English, both in the negotiation of private or public dissatisfaction, and its role in the complex reconceptualization of the phenomenon of globalization as embedded with local meaning given the context of the narrative within the culture of protests. In other words, the use of English indicates the efforts of a country to negotiate its historical, political and cultural imagery with the concept of globalization. In addition, this study will try to portray a new aspect of the relationship between World Englishes and globalization. The examples of protest works presented in this paper show instances of the use of English in countries from the expanding circle.

The guiding research questions for the study were centered around (1) understanding better the "apparatus" of protest banners design as well as the role of the street in protests and (2) how people in different geographically-bound contexts use English to show dissatisfaction to induce global awareness.

\section{Definition and features of protest street art}

Language is not only a tool for communication used for negotiating meaning but language is social action in its own right. Societies create systems of communication which include organizations, governments, rulers and individuals to communicate their attitudes and needs. One of those systems of communication, though not welcomed by governments and rulers, is all the visual and textual material used in street protests. From here on in the text, any visual and textual material used in street protests will be referred to as protest street art because it engages audiences and is a way of expressing unarmed dissatisfaction. Adopting Chaffee's definition, under street art we can understand "the most common forms utilized for political communication - posters, wall-painting, graffiti, and murals" (p.4). Other forms that could be included under this umbrella term are T-shirts, protest banners, and placards. Although all of these can be used individually, in this paper, they are considered as collective ways of communicating a message to both, local and global audiences. Chaffee (1993: 3) also explains, "Because street art is universal in its reach, it should be viewed as a mass communication medium in a general sense." Protest street art is a specific system of communication since it gives opportu- 
nity to the groups who usually have no other means of communicating their needs or beliefs to express those needs freely. In other words, protest street art is a democratic communication tool that everyone who disagrees with a certain regime, establishment, or local event can utilize it.

Protest street art is also used with the intention to promote counter-thinking about the structure of society itself. Another important dimension of street art is that it mirrors the history of a society. When analyzing street art we should approach it as a historical, sociopolitical and linguistic phenomenon. Historically, the pieces of protest street art that are presented in this paper, are contemporary (from the end of $20^{\text {th }}$ and $21^{\text {st }}$ centuries), with an emphasis on socio-political concerns, such as Iranian elections in 2009, NATO bombing of Yugoslavia (Serbia at present), the process of entering of Macedonia in the EU, and Ukrainian events at Maidan (Independence Square). This paper tries to demonstrate what makes protest street art universal.

Several criteria are taken into consideration when creating protest banners: design and color, positioning of the image and words, and conciseness. Making a message simple and easy to grasp is a paramount criterion. This brings us back to the greatest impact that protest art achieves due to the redundancy of complex Standard English linguistic structures.

The major features and functions of protest street art are as follows: (1) it is used as a medium for showing dissatisfaction, identification of problems, making claims and offering solutions, (2) it has a social function, just like language does, (3) it is accessible to everybody, (4) it projects simple discourse and it serves as a tool for minimizing sociopolitical realities to small number of words and phrases to insure world public's understanding, (5) English is used so that subcultures who are striving for recognition under dominant structures can reach broader audiences, (6) it provokes emotions and tension, and (7) it shows that power can be shifted from political leaders and governments to young generations, usually marginal groups, just by using their own creativity and courage. All these complex features show the multifaceted role of protest art.

\section{The role of the street}

Sociologically and historically, the family, the church and the school have been seen as places where processes of socialization happen. A street is seen as a spatial medium used for transportation and movement from one place to another. The street is also connected with violence and negative behavior. However, it is a complex social space in which a network of relationships is built among actors with unequal power and with various beliefs about specific situations filled with social injustice. It is a space where social change occurs. Social space presents itself in the form of agents endowed with dif- 
ferent properties that are systematically linked among themselves (Bourdieu, 1989). In this paper, the street is seen as a space for socialization which happens in protests; a space for democratic participation.

Our perception of the social world is the object of a double structuring: objective and subjective. On the objective side, the world in which we engage is socially structured because the properties attributed to agents or institutions present themselves in unclear combinations. On the subjective side, "it is structured because the schemes of perception and appreciation, especially those inscribed in language itself express the state of relations of symbolic power" (Bourdieu, 1989: 17). Together, these two mechanisms act to produce a common world; a world of commonsense or a minimum consensus of the social world.

The connection between protest art and the street can be made if we approach protest as an alternative political technology (Scartascini \& Tommasi, 2009) including actions such as blocking roads, burning cars and threatening violent action. The more institutions lack the means to perform their duties well, the higher the stimuli for citizens and groups to try to affect the policymaking process through more direct (and less institutionalized) methods, such as protests and demonstrations. This chain cannot be observed separately from the phenomenon of globalization.

\section{Globalization, language and protests}

This study, by exploring the direct link between globalization of English and protest street art, I hope, will contribute to the definitions of English as a global language and as lingua franca.

The modernist principle of "form follows function," that Berns (2009: 196) uses to explain the English usage situation in the EU, is valid for protest street art as well. This paper is trying to bring to the readers' attention the fact that a language used in protest slogans, banners and posters does not need to be standard, and in its full form, for mutual understanding to happen. It is the functions of the language that make English, even in its simplest form, be used as lingua franca in protests. Lingua franca exists because of its simplicity, not because it is a "formal linguistic phenomenon."

According to Crystal, "a language achieves a genuinely global status when it develops a special role that is recognized in every country" (Crystal, 1997: 2). Crystal points out that it doesn't matter how many people speak the language, but who speaks it - "if it is the powerful ones (economically and politically) it is likely to become a global language." In protest art, it is true that it matters who not how many people use a certain type of language; however, it is those who lack political and economic power that construct some discourse and make it global. 
In protest art, the global function of English is manifested in the fact that even if a protest slogan is written in English with simple vocabulary choice, to fully understand the core-meaning of the work, the reader/critic must look beyond what the work is saying, and look at how it says what it is saying, and what it evokes in the audience. Just as in traditional discursive rhetoric, visual rhetoric (protest art) uses strategies and forms to appeal to a specific audience. Both visual and verbal language are conjoined and adapted for specific audiences, purposes and contexts. The use of English in street protests makes this language a social and linguistic reality. All these phenomena form and develop cultural values, literacy, and reinforce social norms at a given moment in history.

A special set of symbols and linguistic forms are used in protests so that the protesters achieve certain ends. That set, because originating from a non-English culture, can be broadly understood if English is used for articulating the language of dissatisfaction and protest. In 2005 Handbook of Visual Communication, Foss discusses the points of what makes an image qualify as visual rhetoric. First, an image must go beyond serving as a sign. Second, there must be some kind of human manipulation in that the symbol must have a process that "involves a conscious decision to communicate as well as conscious choices about the strategies [employed]" (p. 144). Posters, banners, placards, as communication media, must reach their audience quickly as the audience does not spend huge amount of time with the message they show. The more clearly the message is communicated to the target audience through use of image and words, the more successful the call for action will be. In other words, if protesters write the slogan in their native language the issue remains local, but if it is written in English, the protesters feel it becomes global because they will attract the international media.

\section{Analysis of protest work}

In this section protest slogans and banners from four geographical contexts will be analyzed (Iran, Serbia, Macedonia, and Ukraine). Using Bernhardt's (see Girill, 1992) principles of visual rhetoric for positioning sentence fragments that promote prose efficiency, the analysis helped me as a reader and a researcher to unpack much data into a few words, which is the same opportunity writers of banners have. Visually cued text heightens boundaries, edges, and divisions compared to straight prose.

\section{V.1. Election in Iran}

An event that appealed to the international public was 2009 elections in Iran. The 2009 Iranian presidential elections invoked protests against alleged electoral fraud. Protests starting from June 13, 2009, also nicknamed Twitter Revolution, occurred in Tehran and other cities in Iran in support of the opposition candidate Mir-Hossein Mousa- 
vi. Several names including Green Revolution and Persian Awakening were given to the protests reflecting the unsuccessful presidential candidate Mousavi's campaign color (Picture 1). President Mahmoud Ahmedinejad claimed "a statistically unlikely landslide victory over challenger Mir-Hossein Mousavi" (The Independent, June 13, 2009).

The slogan, used massively all around the world, stated "Where is my vote?" as protesters asked why the votes of Mousavi's supporters had not been counted. The purpose for choosing this slogan for this paper is not to show that English was used to reduce socio-political reality to a small number of words which illustrates Gill's principle of localization, but in this case just a simple question was used for a global public comprehension.

If we analyze the slogan "Where is my vote?" linguistically (see Picture 1), we can say that it is a simple interrogative sentence asking where somebody's vote is. However, the answer is not a simple one. The use of English with its instrumental function makes the meaning of this protest slogan more complex. In other words, the question, because written in English, does not only address the issue that the votes for Mousavi's supporters were not counted, but it also raises the awareness of the global public about electoral fraud as an international phenomenon that is happening in front of our eyes. The use of green color adds up to the global meaning of the slogan. According to New York Times reporter Mackey (June 2009), green, which has solid Islamic credentials, was chosen by Mr. Moussavi's supporters as the symbol of their movement to reinforce "the fear among some Iranians that what they are witnessing is a local version of the Orange Revolution, which swept an opposition government into power in Ukraine."

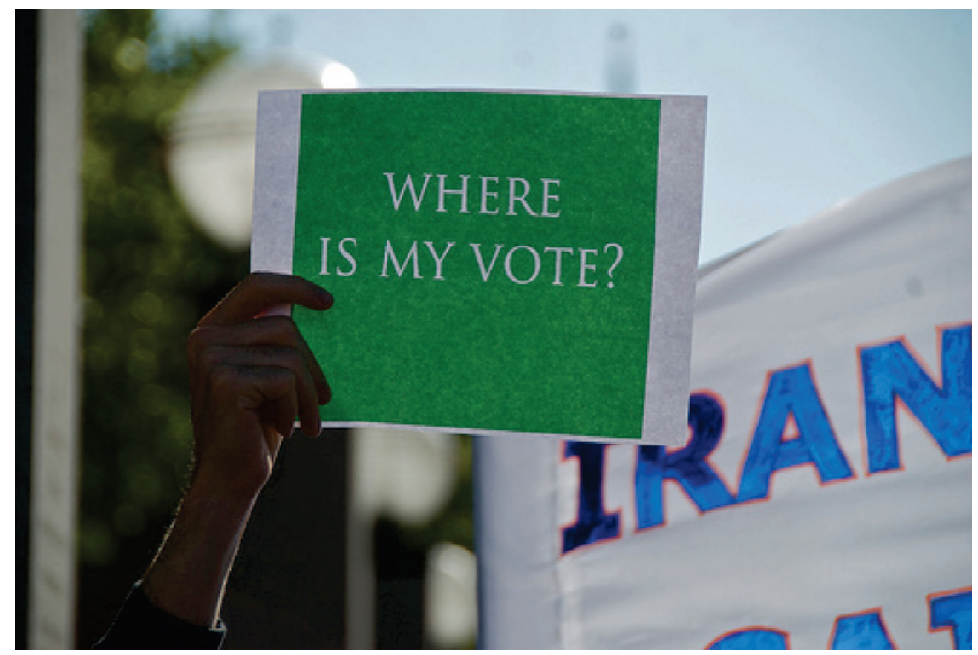

Picture 1 - Iran elections 


\section{V.2. NATO bombing of Yugoslavia-Serbia}

This section presents an analysis of one protest placard from Serbia (formerYugoslavia) during the NATO bombing of former-Yugoslavia. NATO bombing of Yugoslavia, with the code-name Operation Allied Force or, as it was called by the United States, Operation Noble Anvil, lasted from March 1999 to June 1999. The bombing campaign was designed to destroy Serbian air defenses and high-value military targets, and to station an international military presence in Kosovo. One of the main events that triggered the operation was the fact that President Milosevic would not sign the Rambouillet Agreement, which for the Serbs meant signing away all Serbian sovereignty over Kosovo.

Picture 2 presents a young boy showing three fingers, wearing a hat that was worn by the army of King Alexander I Karadzordzevic, the first king of the Kingdom of Yugoslavia and the last king of the Kingdom of Serbs, Croats and Slovenes. What is in the center of audience's attention is the target sign with a question mark. The TARGET sign is multifunctional: (1) it is a symbol of the organization that was in charge of organizing the protests in 1999; (2) together with the question mark it asks who will be next; (3) it resembles the logo of the American chain - Target, as an embodiment of American imperialism, money and globalization, and identifies the United States as the principal member of NATO (Milic, 2003), and finally, (4) the fact that English is used within the Serbian local context indicates that protesters appeal to global public's comprehension of the discontent they feel.

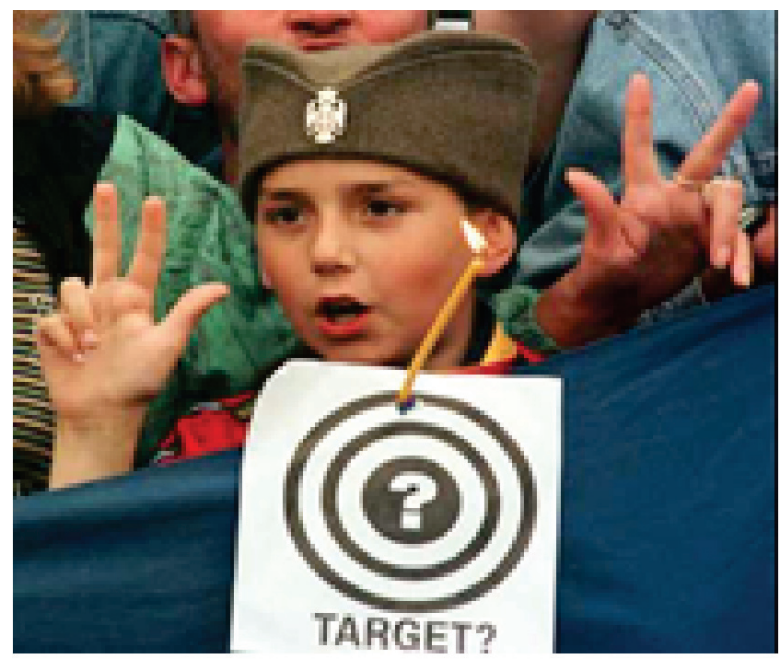

Picture 2 - Bombing in Serbia 


\section{V.3. Macedonia - name issue}

Ever since Macedonia became independent from Yugoslavia in 1991, its name has been the subject of a political dispute with Greece. Greece claims that the use of Republic of Macedonia, as Macedonia calls itself in its Constitution, violates Greece's historic cultural claim to the name, and also implies a territorial claim to the northern Greek province of Macedonia. The name FYROM (the former Yugoslav Republic of Macedonia) was adopted by the United Nations when the country got admitted to the organization in 1993 (United Nations Resolution 225, April, 1993). Most international organizations, such as the EU, the European Broadcasting Union, and the International Olympic Committee, adopted the same name. Walter Schwimer, former Secretary General of the Council of Europe (CoE), in March 2004, obliged CoE to use "Former Yugoslav Republic of Macedonia" and denotation "citizens of FYROM" for the Macedonians, which provoked a series of protest notes and letters to the Council of Europe, while the NGO sector started a mass campaign named Don't You FYROM Me! A whole campaign, also known as Say Macedonia, started in March 2004 in Skopje, the capital of Macedonia. Say Macedonia campaign included distribution of posters, fliers, T-shirts (as shown in the picture above) and postcards with the slogans "Don't You F.Y.R.O.M. Me" and "Call Me By My Name."

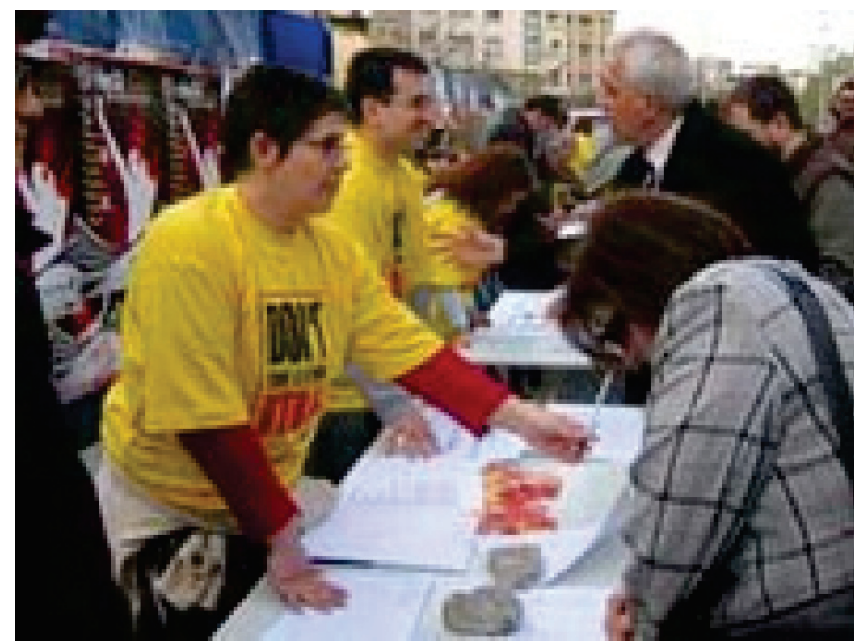

Picture 3 - Macedonia - name issue

If we analyze the slogan Don't You FYROM Me! linguistically (see Picture 3), we can say that it is a simple imperative sentence requesting a different way of addressing a nation. The acronym F.Y.R.O.M from a noun was converted into a verb and 
the linguistic process of conversion means that a word used as one part of speech may fulfill a different function in a different context. Used as a verb the acronym gains more power. The use of English with its instrumental function makes the meaning of this protest slogan more complex. In other words, because written in English, the slogan does not only address the local dispute with a neighboring country, but it also raises the awareness of the global public about the treatment of a nation and its identity. The use of the yellow and red colors adds up to the global meaning of the slogan, since those are the colors of the Macedonian national flag.

\section{V.4. Ukraine - Oranges}

In Ukraine, in 2004-2005 mass protests, known as Orange Revolution, lasting for two months helped the pro-Western President Viktor Yushchenko to be elected for president. He defeated his rival Viktor Yanukovych in a repeat run-off election. In 2013, nine years after the Orange Revolution Ukrainians got massively in the streets and Maidan Independence Square against the rule of Mr Yanukovych. These mass demonstrations were triggered by Yanukovych government's decision not to sign a wide-ranging association agreement with the European Union, because of the pressure from Russia. Both domestic and external factors played a role in restricting the autocratic power and through the international financial and intellectual resources fraud was revealed. Picture 4 shows one sign of disapproval of the uneducated president's wife and fraudulent actions of the president. What is presented is a toy/doll

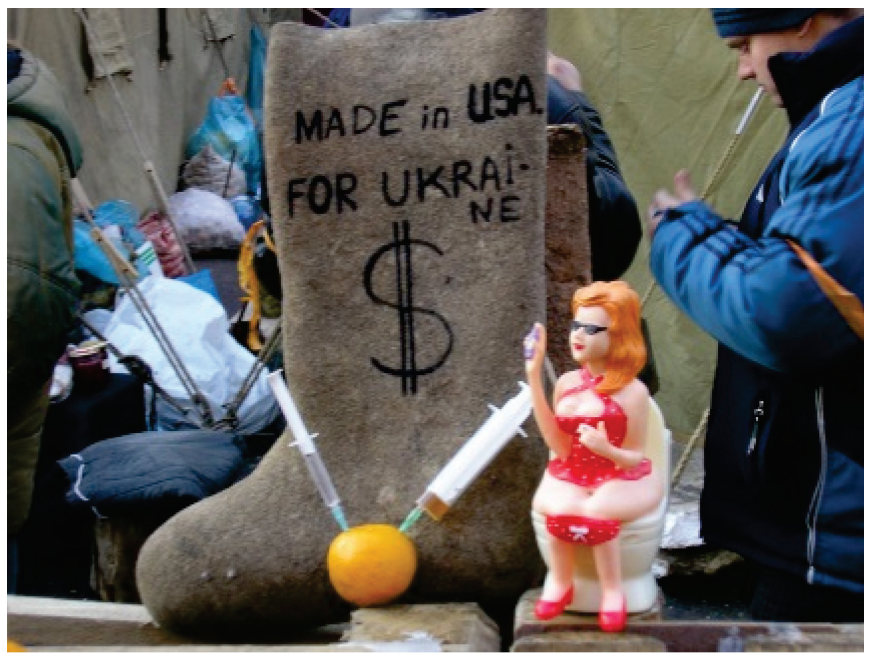

Picture 4 - Ukraine - Oranges 
with the former first lady Liudmila Yanukovych sitting on a toilet seat, two shots in an orange and a stone with the inscription stating "Made in USA for Ukraine \$." During the revolution days in 2004, she became famous because of the speech she made at the meeting of her husband's proponent. According to her, Americans injected oranges with drugs and gave them to people standing on Maidan so that they would become intoxicated, act crazy and promote Westerns values.

The short message and the dollar sign, not even a full sentence, point to the instrumental function of the language as it is written in English in order to address the foreign institutions and transform the local context into a global one. The use of the real orange points to the multimodality imaging. The principles of visual rhetoric are applied by positioning sentence fragments in which much socio-historical data is packed into a few words to promote prose efficiency.

\section{Conclusion}

This paper examines the function of English in foreign countries as a means of no-arms unrest and it looks at the role of the street in the process of socialization through democratic participation. Through the examples of protest banners described in this study, an attempt has been made to show that English is highly embedded within local contexts of foreign countries.

The analysis of the socio-political and historical factors impacting the change of the role of protest art shows that English has been more extensively used in protests and it has contributed to protest works becoming socio-historical tools for anyone with a need to communicate. Protesters create worlds where oppression is fought against through street art. In this process simple English phrases combined with images become a weapon of the dissatisfied, politically and economically less powerful ones.

This phenomenon is all the more challenging when one considers the importance of language in the formation of national identity, which often takes precedent even over geography itself. The use of English as lingua franca in protests helps people show sense of belonging to the global world in which social and political injustice exist. But the use of English and the visual rhetoric are not enough for street protest art to be defined as specific system of communication. The street, with all its complexity, gives opportunity to the groups who usually have no other means of communicating their needs or beliefs to express those needs freely. The street enhances the power of the politically underprivileged ones. This is possible because beyond the emotional factors rooted in dissatisfaction, there are specific factors such as group affiliation, shared intentionality and socio-cultural consequences which become visible in the street when an individual blends with the crowd into a joint activity. 


\section{REFERENCES}

Berns, M. (2009). English as Lingua Franca and English in Europe. World Englishes, 28(2), $192-$ 199.

Bourdieu, P. (1989). Social space and power. Sociological Theory, 7(1), 14-25.

Chaffee, L.G. (1993). Political protest and street art: Popular tools for democratization in Hispanic countries. Westport, Connecticut: Greenwoodpress.

CNN world news (2009, June 13). Ahmadinejad hails election as protests grow. CNN. Retrieved November 20, 2009 from http://edition.cnn.com/2009/WORLD/meast/06/13/iran.election/index.html

Crystal, D. (1997). Why a Global Language? In English as a Global Language (pp. 1-23). Cambridge: Cambridge University Press.

Foss, S. K. (2005). Theory of visual rhetoric. In K. Smith, S. Moriarty, G. Barbatsis, \& K. Kenney (Eds.), Handbook of Visual Communication: Theory, methods, and media (pp. 179-189). Mahwah, NJ: Lawrence Erlbaum Associates.

Girill, T. R. (1992). The principles of visual rhetoric and the rhetoric of visual principles. ACM SIGDOC Asterisk Journal of Computer Documentation, 16(3), 17-26.

Mackey, R. (2009, June 10). A Green Revolution for Iran? New York Times. Retrieved November 20, 2009 from http://thelede.blogs.nytimes.com/2009/06/10/a-green- revolution-for-iran

Milic, L. (2003). From Serbia with Hate: A Case Study in Globalization, Trauma, and Language. Dialectical Anthropology 27: 331-353.

North Atlantic Treaty Organisation. The situation in the former Yugoslav Republic of Macedonia is critical. Retrieved November 20, 2009 from http://www.nato.int/docu/update/2001/0723/e0725a.htm

Phillipson, R. (1997). Realities and Myths of Linguistic Imperialism. Journal of Multilingual and Multicultural Development, 18(3), 238-248.

Scartascini, C., \& Tommasi, M. (2009). The Making of Policy: Institutionalized or Not? IDB Working Paper 108. Washington, DC, United States, Inter-American Development Bank. 
Мира Беќар

Сажетейк

Универзитет Св. Ћирило и Методије, Филолошки факултет „Блаже Конески“

Скопље, Македонија

\section{ПРОСТОР, ЈЕЗИК И МОЋ: РЕТОРИКА УЛИЧНИХ ПРОТЕСТА}

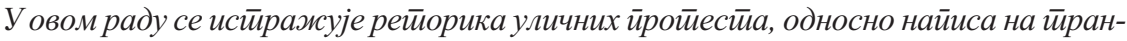
сйаренйима и слоїана као начина да се изрази незадовољсииво, али и значај улице у којој се мрежка односа іради међу акиетерима неједнаке моћи и различийх уверења о сиеецифбичним друитивеним сийуацијама. Осланајући се на Бернсово (Berns 1995: 195) йлдишіие да за људе „21. века, еніллески језик служи великом броју сврха, не само за конйакӣе лицем у лище већ и йуием средстиава масовних комуникација и медија, укључујући шииамйу, аудио-визуелне и елекйронске медије, више неі̄о икада раније у иситорији“, као и на Бурдијеову (Bourdieи 1989) расйраву о симболичим борбама око иеерцейиије друшиивених свейова, овај рад се фокусира на однос између уйойребе еніллеской језика као средсиива изражсавања незадовољсиива на йлобалном нивоу, као и на улици, їде се он корисиии као средстиво за изражаване заједничке друийвене акиије. Анализа је-

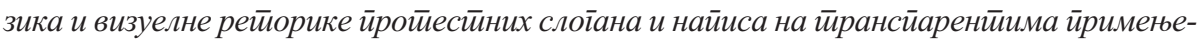
на је у овом раду уз ослонац на иринцийе визуелне рейорике. Локални кониеексй укључује Иран, Србију, Македонију и Украјину. Ова истиражсивачка сӣудија ӣоказује на који начин су усклађени локална исииоријска и йолииччка ӥредстиављана са осећањем

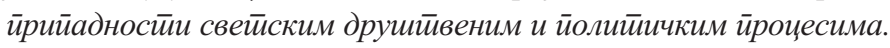

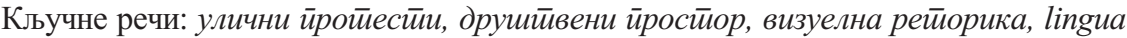
franca, moћ. 